This item was submitted to Loughborough's Research Repository by the author.

Items in Figshare are protected by copyright, with all rights reserved, unless otherwise indicated.

\title{
Doubling sensitivity in multicollector ICPMS using high-efficiency, rapid response laser ablation technology
}

PLEASE CITE THE PUBLISHED VERSION

https://doi.org/10.1021/acs.analchem.8b02896

\section{PUBLISHER}

(C) American Chemical Society

\section{VERSION}

AM (Accepted Manuscript)

\section{PUBLISHER STATEMENT}

This document is the Accepted Manuscript version of a Published Work that appeared in final form in Analytical Chemistry, copyright $\odot$ American Chemical Society after peer review and technical editing by the publisher. To access the final edited and published work see https://pubs.acs.org/doi/10.1021/acs.analchem.8b02896.

\section{LICENCE}

CC BY-NC-ND 4.0

\section{REPOSITORY RECORD}

Craig, Grant, Amy Managh, Ciprian Stremtan, Nicholas S. Lloyd, and Matthew S. Horstwood. 2019. "Doubling Sensitivity in Multicollector ICPMS Using High-efficiency, Rapid Response Laser Ablation Technology". figshare. https://hdl.handle.net/2134/35032. 


\title{
Doubling sensitivity in MC-ICP-MS using high-efficiency, rapid- response laser ablation technology.
}

\author{
Grant Craig, ‡* Amy J. Managh, † Ciprian Stremtan, † Nicholas S. Lloyd $\neq$ and Matthew S. A. Horst- \\ wood II \\ ‡ Thermo Fisher Scientific (Bremen) GmbH, Hanna-Kunath Str. 11, 28199 Bremen, Germany \\ $\dagger$ Department of Chemistry, Loughborough University, Loughborough, Leicestershire, LE11 3TU, UK \\ + Teledyne CETAC Technologies, Omaha, USA \\ ॥ NERC Isotope Geosciences Laboratory, British Geological Survey, Nicker Hill, Keyworth, Nottingham NG12 5GG, UK
}

\begin{abstract}
The introduction of rapid-response laser ablation cells and sample transport technologies to laser ablation inductively coupled plasma mass spectrometry (LA-ICP-MS) has enabled signal pulse durations for a single laser ablation shot of less than 10 ms. These developments have resulted in marked improvements in analytical throughput, resolution and sensitivity vital for the generation of large, highly spatially-resolved elemental maps. The focus on mapping, particularly bioimaging, has obscured the possibility of applying the sensitivity advantage of rapid-response technologies to other LA-ICP-MS applications, such as high precision isotope ratio analysis on multicollector (MC-)ICP-MS. In this work a commercially available rapid-response sample transport system and a conventional configuration were compared for LA-MC-ICP-MS analysis. Ablation of known reference materials demonstrated 'sensitivity' or sample ion yield of 7-9\% using the rapid-response sample transport system, more than double that for the conventional set-up. This increase in efficiency was demonstrated to improve precision for the $\mathrm{Pb}$ isotope ratio analysis of the MPI-DING reference glasses and improve the spatial resolution of Hf isotope ratio analysis of reference zircons.
\end{abstract}

The achievable precision during mass spectrometry is a function of the amount of material sampled and the detection efficiency of the combined sample introduction system and mass spectrometer. Without limitation from the amount of sample, high precision can be easily achieved, even with a system featuring low detection efficiency, simply by measuring the analyte for a prolonged period of time. For some challenging applications, and sample introduction techniques such as laser ablation, however, the amount of sample material which is available is fundamentally limited. Here using a high detection efficiency method enables smaller amounts of sample to be used whilst still maximizing precision. In geoscience using laser ablation as the sample introduction technique for an inductively coupled plasma mass spectrometer (LA-ICP-MS), many commonly analyzed isotopes can be rapidly measured in situ within containing minerals. To confidently interpret changes in zonation requires constraining the area or volume ablated. Therefore to maintain the analytical precision required under these spatial constraints requires the highest efficiency.

Recent years have seen the development ${ }^{1-3}$, and subsequent commercialization (Teledyne CETAC ${ }^{\mathrm{TM}}$ ARISTM Aerosol Rapid Introduction System, ESI NWR ${ }^{\mathrm{TM}}$ Bloodhound ${ }^{\mathrm{TM}}$ ), of rapid response laser ablation cells and sample transport technologies. Their designs are aimed towards minimizing aerosol dispersion in the cell and substantially reducing the washout time $^{4}$. Upon leaving the cell the low dispersion aerosol must be transported to the ICP-MS. As aerosol dispersion also occurs within the transport tubing and injector of the ICP torch, rapid response laser ablation cell designs have also incorporated changes to these elements of the LA-ICP-MS configura- tion ${ }^{1-4}$. Reductions in transport tubing diameter and elimination of injector dead volumes have been seen to minimize aerosol dispersion ${ }^{3,4}$. However reducing the diameter of the transport tubing decreases the mass flux outflow from the cell. If the ablated particle density exceeds what the transport tubing can efficiently extract then the excess material can either be lost (e.g., gravitational sedimentation or inertial deposition), reducing efficiency, or is only released after a significant delay, reducing speed and throughput efficiency or producitivity ${ }^{5}$.

The key driver in these developments has been to improve the utility of LA-ICP-MS for sample mapping, primarily for determining the distribution and concentration of drugs or tagged biomarkers in tissue sections or single cells. For ablation cell designs with washout $\approx 500 \mathrm{~ms}$, high resolution sample mapping requires using a slow laser pulse repetition rate in order to restrict signal overlap between adjacent image pixels: resulting in long analysis times. In practice high repetition rates have also been used, sacrificing pixel resolution in favor of time. The prototype designs on which the current commercially available rapid response ablation cells were based both reported sub-5 ms washout ${ }^{2,3}$. As such completely resolved pixels could be collected at rates $>150 \mathrm{~Hz}$, greatly reducing the analysis time (commercial designs $40 \mathrm{~Hz}^{6}$ ). The corresponding improvements in signal-to-noise ratio, lowering the limit of detection, allows the use of smaller spot sizes further improving resolution. $5 \mu \mathrm{m}$ resolution mapping of the binding of platinum-based anti-cancer compounds to both cochlea ${ }^{7}$ and multi-cellular tumor spheroids ${ }^{8}$ have recently been reported. Van Malderen et al. (2017) produced a fully resolved trace ele- 
mental distribution map of a crustacean at $2 \mu \mathrm{m}$ resolution ${ }^{9}$. Although rapid response cells were designed for bio-imaging applications, they also have applicability to the more established LA-ICP-MS applications of geochemistry and isotope ratio analysis. Petrus et al. (2017) produced large, 5.5 x 5.0 $\mathrm{mm}$, trace elemental distribution maps of serpentinized peridotite and augite in less than 2 hours ${ }^{10}$.

To be best utilized, rapid response laser ablation cells and transport technologies demand an ICP-MS with a short duty cycle. For trace elemental analysis this condition can be met by a fast scanning ICP-Q-MS or ICP-TOF-MS, but for isotope ratio analysis there is another option. Multi-Collector (MC)ICP-MS has become a well-established technique for high precision isotope ratio measurements, especially in the field of geochemistry. Here the issues of spectral skew observed for rapid response ablation cells on scanning mass spectrometers ${ }^{6}$ should be eliminated as every isotope is collected simultaneously. It should be noted this is only true if the same type of detector is used for each isotope as a form of spectral skew has been reported for MC-ICP-MS with a mixed SEM/Faraday cup detector array ${ }^{11}$. LA-MC-ICP-MS is routinely used to measure a variety of isotopic systems, including $\mathrm{Hf}^{12,13}$ and $\mathrm{U} / \mathrm{Pb}^{14-16}$ in zircon geochronology, at a variety of precision levels. Developments such as the Jet Interface and $10^{13} \Omega$ amplifier technology ${ }^{17,18}$ for the Thermo Scientific ${ }^{\text {TM }}$ NEPTUNE Plus $^{\mathrm{TM}}$ and enhanced sensitivity HR-ES ${ }^{19}$ for the Nu Instruments $^{\mathrm{TM}} \mathrm{Nu}$ Plasma ${ }^{\mathrm{TM}}$ MC-ICP-MS have already delivered significant improvements in signal-to-noise ratio, and hence LA-MC-ICP-MS spatial resolution. Rapid response laser ablation cells have already been reported to deliver significant improvements in signal-to-noise for LA-ICP-MS and here we report on the application of one of these designs to LA-MCICP-MS.

Sample Ion Yield. ICP-MS instrument sensitivity is typically reported as the number of ions detected against the concentration of the measured isotope in the sample (cps/ppm for QICP-MS or V/ppm for MC-ICP-MS). However, reporting sensitivity in this manner is not necessarily the best unit of comparison as it ignores the extent to which the signal intensity is dependent on the rate at which the sample is introduced ${ }^{20}$. Nominally, an analyte in a solution introduced at a flow rate of $200 \mu \mathrm{L} / \mathrm{min}$ would yield a peak signal and apparent sensitivity (in $\mathrm{cps} / \mathrm{ppm}$ ) twice that using a solution introduced at 100 $\mu \mathrm{L} / \mathrm{min}$, making comparison between different ICP-MS configurations difficult if flow rate isn't taken into account. For LA-ICP-MS, sample introduction rate is dependent on a complex series of factors (including fluence, spot size, and repetition rate and sample matrix). Another reporting method is therefore clearly required, ideally one appropriate for both solution and laser ablation sample introduction.

The sample ion yield (also referred to elsewhere as 'useful yield' and 'detection efficiency'), the ratio of the number of ions detected against the number of atoms sampled, is a method for reporting sensitivity commonly used in TIMS and SIMS mass spectrometry. A significant advantage of reporting the sample ion yield is that it is independent of the rate at which the sample is introduced; nominally the ratio of ions detected to atoms sampled should remain the same. The number of atoms can be calculated for a measured volume of material provided the elemental concentration and isotopic composition of the material are known. The mass response curve of the mass spectrometer (as well as other factors) however, de- termines that the sample ion yield is dependent on the isotope that is measured. The highest sample ion yields are usually reported for the highest mass elements, such as $\mathrm{Pb}$ and $\mathrm{U}$ (in MC-ICP-MS and SIMS).

LA-MC-ICP-MS is already amongst the more sensitive mass spectrometry techniques. Schaltegger et al. (2015) reported sample ion yields of $2 \%$ and $2.8 \%$ for $\mathrm{Pb}$ and $\mathrm{U}$ respective$1 y^{14}$. A complementary technique, SIMS, when optimized for transmission, can achieve similar sample ion yields for these elements $^{21}$. The sample ion yield reported for TIMS is more dependent on the element ionization potential (and the filament loading technique) than ICP-MS. U \& $\mathrm{Pb}$ sample ion yields can be significantly higher than for MC-ICP-MS $(\approx 10$ $\%)^{22}$, but are usually broadly equivalent ${ }^{23}$.

The only previous application of a rapid response ablation cell to a MC-ICP-MS, focused on a single application and with an experimental prototype cell, suggested LA-MC-ICP-MS may be capable of significantly greater sample ion yields ${ }^{11}$. Here we report the first coupling of a MC-ICP-MS (NEPTUNE Plus) to a commercially available (ARIS) rapid response sample transport technology. The impact on instrument sensitivity (as sample ion yield) was quantified for a suite of elements ( $\mathrm{Li}, \mathrm{Sr}, \mathrm{Nd}, \mathrm{Hf}, \mathrm{Pb}$ and $\mathrm{U}$ ) across the total mass range and compared to that provided by a more conventional laser ablation cell. Subsequently the configuration was tested for $\mathrm{Hf}$ and $\mathrm{Pb}$ isotope ratio analysis for a series of well characterized reference materials.

\section{EXPERIMENTAL SECTION}

All MC-ICP-MS measurements were carried out on the NEPTUNE Plus at Thermo Fisher Scientific (Bremen) GmbH. In order to maximize instrument ion yield across the mass range the Jet Interface option was used with the $\mathrm{X}$ skimmer and Jet sampler cone. $\mathrm{N}_{2}$ addition was also used. The laser ablation system used was a Teledyne Photon Machines ${ }^{\mathrm{TM}}$ Analyte G2 ${ }^{\mathrm{TM}}$.

In the high efficiency, rapid response ablation cell configuration, the inner cell of the HelEx ${ }^{\mathrm{TM}}$ ablation cell was coupled directly to the MC-ICP-MS torch injector via the ARIS. The transfer line consisted of $1.5 \mathrm{~m}$ of PEEK tubing, $1 \mathrm{~mm}$ internal diameter. Ar and $\mathrm{N}_{2}$ were added via the ARIS adapter.

In the conventional configuration the output of the inner cup was connected to a Teledyne Photon Machines ${ }^{\mathrm{TM}}$ CleanShot $^{\mathrm{TM}}$ sample transport accessory. The CleanShot ${ }^{\mathrm{TM}}$ allows for the aerosol to be transported in a straight line to the ICP by bypassing all the internal transport tubing and switching valves, thus shortening the transport path and reducing the aerosol transport time. The CleanShot was connected to the HelEx cell by $2 \mathrm{~m}$ of $4 \mathrm{~mm}$ outer diameter, $2 \mathrm{~mm}$ internal diameter, Teflon ${ }^{\circledR}$ tubing and to the ICP injector by $1.5 \mathrm{~m}$ of $1 / 4$ " outer diameter Teflon coated Tygon ${ }^{\mathrm{TM}}$ tubing. Ar and N2 make-up gasses were added via two nylon y-pieces.

The methodology applied to tuning a LA-MC-ICP-MS is dependent on the isotope ratios being measured. For experiments which focus on intra-element isotope ratios, such as those for $\mathrm{Pb}$ or $\mathrm{U}$, issues of laser-induced elemental fractionation or oxide formation rates are not necessarily principle factors during instrument tuning. In these instances the system can be tuned for maximum 'sensitivity' and these therefore represent the best achievable sample ion yield. However for Hf isotopic analysis, the required corrections for $\mathrm{Lu}$ and $\mathrm{Yb}$ interferences are negatively impacted at high oxide conditions due to the 
different oxide formation rates of each element. Furthermore potential Gd and Dy oxide interferences are more likely to occur in high oxide conditions ${ }^{24}$. $\mathrm{Nd}$ isotopic analysis is similarly affected by the required ${ }^{144} \mathrm{Sm}$ correction on both the determined ${ }^{143} \mathrm{Nd} /{ }^{144} \mathrm{Nd}$ and ${ }^{146} \mathrm{Nd} /{ }^{144} \mathrm{Nd}$ used for mass bias correction $^{25}$. For these isotope systems the LA-MC-ICP-MS needs to be optimized to minimize laser-induced elemental fractionation and rates of oxide formation at the expense of maximum sample ion yield. The sample ion yield was therefore determined for the two possible states, optimized and maximum $U$ ion yield, with both the conventional and high efficiency configurations (Table 1). 


\begin{tabular}{|c|c|c|c|c|c|}
\hline & & $\begin{array}{l}\text { Conventional } \\
\text { Optimized }\end{array}$ & $\begin{array}{l}\text { Conventional } \\
\text { Maximum Ion yield }\end{array}$ & $\begin{array}{l}\text { High Efficiency } \\
\text { Optimized }\end{array}$ & $\begin{array}{l}\text { High Efficiency } \\
\text { Maximum Ion yield }\end{array}$ \\
\hline \multicolumn{6}{|c|}{ Thermo Scientific NEPTUNE Plus MC-ICP-MS } \\
\hline Cool Gas & $\mathrm{L}_{\min ^{-1}}$ & 16 & 16 & 16 & 16 \\
\hline Aux Gas & $\mathrm{L}_{\mathrm{min}^{-1}}$ & 0.75 & 0.90 & 0.75 & 0.95 \\
\hline Sample Gas & $\mathrm{L} \min ^{-1}$ & 0.72 & 0.90 & 0.95 & 1.085 \\
\hline Z & $\mathrm{mm}$ & -1.95 & -1.45 & -1.95 & -1.95 \\
\hline Power & $\mathrm{W}$ & 1200 & 1300 & 1300 & 1300 \\
\hline Integration Time & $\mathrm{ms}$ & 131 & 131 & 131 & 131 \\
\hline \multicolumn{6}{|c|}{ Photon Machines Analyte G2 $193 \mathrm{~nm}$ excimer laser ablation system } \\
\hline $\mathrm{He}-$ Outer Cell & $\mathrm{L}_{\mathrm{min}^{-1}}$ & 0.50 & 0.60 & 0.425 & 0.20 \\
\hline $\mathrm{He}-$ Cup Flow & $\mathrm{L} \mathrm{min}^{-1}$ & 0.30 & 0.35 & 0.15 & 0.15 \\
\hline $\mathrm{N}_{2}$ Addition & $\mathrm{mL} \min ^{-1}$ & 9.0 & 9.0 & 8.5 & 9.5 \\
\hline $\mathrm{UO} / \mathrm{U}$ & $\%$ & 0.107 & 0.930 & 0.092 & - \\
\hline${ }^{238} \mathrm{U} /{ }^{232} \mathrm{Th}$ & & 1.131 & 1.794 & 1.088 & - \\
\hline
\end{tabular}

Table 1. LA-MC-ICP-MS parameters on the NEPTUNE Plus MC-ICP-MS and Analyte G2 laser ablation system. Tuning was performed for a line raster of NISTTM SRM ${ }^{\circledR} 610,4 \mathrm{~J} \mathrm{~cm}^{-2}$ fluence, $7 \mathrm{~Hz}$ repetition rate, $35 \mu \mathrm{m}$ spot size. Three isotopes ${ }^{232} \mathrm{Th},{ }^{238} \mathrm{U}$ and ${ }^{238} \mathrm{UO}$ were monitored simultaneously. The optimized conditions (Conventional and High Efficiency) were tuned to minimize fractionation between ${ }^{232} \mathrm{Th}$ and ${ }^{238} \mathrm{U}$ and reduce ${ }^{238} \mathrm{UO} /{ }^{238} \mathrm{U}$ as far as possible. The maximum ion yield conditions were tuned to maximize the response for ${ }^{238} \mathrm{U}$.

The sample ion yield was measured for six isotopic systems ( $\mathrm{Li}, \mathrm{Sr}, \mathrm{Nd}, \mathrm{Hf}, \mathrm{Pb}$ and $\mathrm{U}$ ) using the cup configurations provided in Table 2 . Four replicates of fifty shots were fired at a rate of $1 \mathrm{~Hz}$, fluence $4 \mathrm{~J} \mathrm{~cm}^{-2}$, into a mounted piece of SRM ${ }^{\circledR} 610$ glass from NIST. Five different spot sizes ranging from $10 \mu \mathrm{m}$ to $110 \mu \mathrm{m}$ were measured. As the glass density and concentration of the six elements measured is known for SRM610, it was possible to calculate the number of atoms introduced for each element from the volume of the crater ablated. The volume of each crater was measured using a 3D optical microscope (InfiniteFocus ${ }^{\mathrm{TM}}$, Aliconia, Sevenoaks, UK).

Pb Isotopic Analysis of MPI-DING Reference Materials. The determination of the isotope ratios of lead $\left({ }^{208} \mathrm{~Pb} /{ }^{206} \mathrm{~Pb}\right.$, ${ }^{207} \mathrm{~Pb} /{ }^{206} \mathrm{~Pb}$ ) was used to evaluate the performance of the high efficiency rapid response cell when tuned for maximum sample ion yield. Ten spots were each ablated $\left(3 \mathrm{~J} \mathrm{~cm}^{-2}\right.$ fluence, $40 \mu \mathrm{m}$ circular spot size, $16 \mathrm{~Hz}$ repetition rate) in three of the MPI-DING series of reference glasses (ATHO-G, StHs6/80-G, GOR132-G). For each analysis a further ten spots on the NIST SRM $® 612$ glass were used as the primary reference analyses.

A high repetition rate is required with rapid response ablation cells in order to ensure a stable signal profile ${ }^{7,10}$. Measuring on the central SEM of the MC-ICP-MS the washout time of the high efficiency configuration was estimated to be less than $100 \mathrm{~ms}$ (50 ms, full peak width at $10 \%$ maximum), requiring $20 \mathrm{~Hz}$ or greater repetition rate to achieve a signal profile which did not resolve the individual pulse tops. However, analogue Faraday detectors are principally used in MCICP-MS which introduce a significant degree of smoothing (dependent on the resistance of the associated amplifier) to the signal profile when compared to an SEM. A detector array equipped only with Faraday cup detectors can achieve a stable signal profile for repetition rates less than $10 \mathrm{~Hz}$, due to the signal smoothing from the associated amplifier.

${ }^{206} \mathrm{~Pb}$ and ${ }^{207} \mathrm{~Pb}$ were measured on Faraday cup detectors equipped with $10^{13} \Omega$ amplifiers, all other isotopes were measured on $10^{11} \Omega$ amplifiers. Tau correction of the $10^{13} \Omega$ amplifiers was performed within the Neptune/Triton v3.3.0 software. All data were processed within Iolite ${ }^{\mathrm{TM}} \mathrm{v} 3.63$ using an in-house data reduction scheme.

Hf isotope ratio and $\mathrm{U} / \mathrm{Pb}$ geochronology of reference zircons. The determination of ${ }^{176} \mathrm{Hf} /{ }^{177} \mathrm{Hf}$ in two reference zircons, 91500 and Plešovice, was used to evaluate the utility of the high efficiency rapid response cell for analyses which need to be optimized for low oxide formation. The laser ablation parameters (Table 3) followed the small-volume method reported in Bauer \& Horstwood (2017) ${ }^{13}$. For each analysis twenty spots on Plešovice and twenty spots on the reference material 91500 zircon were ablated. 


\begin{tabular}{|l|c|c|c|c|c|c|c|c|c|}
\hline Cup Configuration & L4 & L3 & L2 & L1 & C & H1 & H2 & H3 & H4 \\
\hline $\mathrm{Li}$ & & & & & ${ }^{7} \mathrm{Li}$ & & & & \\
\hline $\mathrm{Sr}$ & & ${ }^{82} \mathrm{Kr}$ & ${ }^{83} \mathrm{Kr}$ & ${ }^{84} \mathrm{Sr}$ & ${ }^{85} \mathrm{Rb}$ & ${ }^{86} \mathrm{Sr}$ & ${ }^{87} \mathrm{Sr}$ & ${ }^{88} \mathrm{Sr}$ & \\
\hline $\mathrm{Nd}$ & & ${ }^{142} \mathrm{Nd}$ & ${ }^{143} \mathrm{Nd}$ & ${ }^{144} \mathrm{Nd}$ & ${ }^{145} \mathrm{Nd}$ & ${ }^{146} \mathrm{Nd}$ & ${ }^{147} \mathrm{Sm}$ & ${ }^{148} \mathrm{Nd}$ & \\
\hline $\mathrm{Hf}$ & & ${ }^{171} \mathrm{Yb}$ & ${ }^{173} \mathrm{Yb}$ & ${ }^{175} \mathrm{Lu}$ & ${ }^{176} \mathrm{Hf}$ & ${ }^{177} \mathrm{Hf}$ & ${ }^{178} \mathrm{Hf}$ & ${ }^{179} \mathrm{Hf}$ & \\
\hline $\mathrm{Pb}$ & & ${ }^{202} \mathrm{Hg}$ & ${ }^{203} \mathrm{Tl}$ & ${ }^{204} \mathrm{~Pb}$ & ${ }^{205} \mathrm{Tl}$ & ${ }^{206} \mathrm{~Pb}$ & ${ }^{207} \mathrm{~Pb}$ & ${ }^{208} \mathrm{~Pb}$ & \\
\hline $\mathrm{U}$ & & & ${ }^{234} \mathrm{U}$ & ${ }^{235} \mathrm{U}$ & ${ }^{236} \mathrm{U}$ & & ${ }^{238} \mathrm{U}$ & & \\
\hline $\mathrm{U} / \mathrm{Pb}$ & ${ }^{206} \mathrm{~Pb}$ & ${ }^{207} \mathrm{~Pb}$ & ${ }^{208} \mathrm{~Pb}$ & & & & ${ }^{232} \mathrm{Th}$ & ${ }^{235} \mathrm{U}$ & ${ }^{238} \mathrm{U}$ \\
\hline
\end{tabular}

Table 2. Table of MC-ICP-MS cup configurations used. ${ }^{206} \mathrm{~Pb}$ and ${ }^{207} \mathrm{~Pb}$ were measured on $10^{13} \Omega$ amplifiers in both the $\mathrm{Pb}$ and $\mathrm{U} / \mathrm{Pb}$ configurations. All other isotopes were measured with $10^{11} \Omega$ amplifiers.

Further spots were used to collect $\mathrm{U} / \mathrm{Pb}$ for the same two zircons, but with a lower laser energy and duration than for Hf. All data were processed within Iolite v3.63 using an inhouse Hf data reduction scheme and the supplied U$\mathrm{Pb}$ Geochronology 4 data reduction scheme. $1 \mathrm{~s}$ was cropped from the beginning and end of each analysis.

Table 3. Laser ablation parameters for $\mathrm{Hf}$ and $\mathrm{U} / \mathrm{Pb}$ isotope analysis of 91500 and Plešovice zircons.

\begin{tabular}{|l|l|l|l|}
\hline Parameter & \multicolumn{2}{|l|}{ Hf } & $\mathrm{U} / \mathrm{Pb}$ \\
\hline Fluence & $6.5 \mathrm{~J} \mathrm{~cm}^{-2}$ & $6.5 \mathrm{~J} \mathrm{~cm}^{-2}$ & $3 \mathrm{~J} \mathrm{~cm}^{-2}$ \\
\hline Spot Size & $25 \mu \mathrm{m}$ circle & $20 \mu \mathrm{m}$ circle & $20 \mu \mathrm{m}$ circle \\
\hline $\begin{array}{l}\text { Repetition } \\
\text { Rate }\end{array}$ & $10 \mathrm{~Hz}$ & $10 \mathrm{~Hz}$ & $10 \mathrm{~Hz}$ \\
\hline Duration & $10 \mathrm{~s}$ & $10 \mathrm{~s}$ & $5 \mathrm{~s}$ \\
\hline
\end{tabular}

\section{RESULTS \& DISCUSSION}

Sample Ion Yield. The sample ion yield of the high efficiency configuration was found to be dependent on the spot size ablated (Table 4). The sample ion yield of the conventional configuration was the same regardless of spot size (Table 5). This effect has been observed before with high efficiency laser ablation designs: at the largest spot sizes the transient ablated particle density is greater than the mass flux outflow of the cell into the transport tubing of the high efficiency design and thus not all of the material can be efficiently extracted ${ }^{5,11}$.

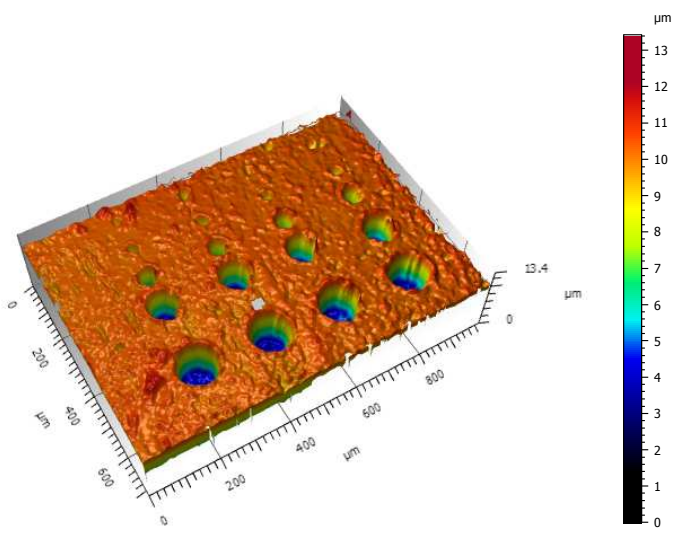

Figure 2. False color 3D image, created with an InfiniteFocus 3D microscope, of spot craters in SRM610 glass.

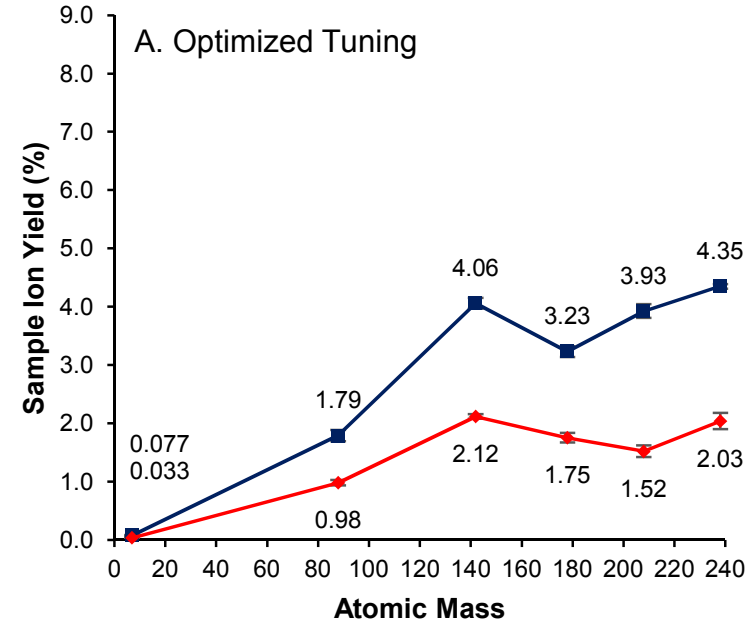

$\rightarrow$-High Efficiency $\longrightarrow$ Conventional

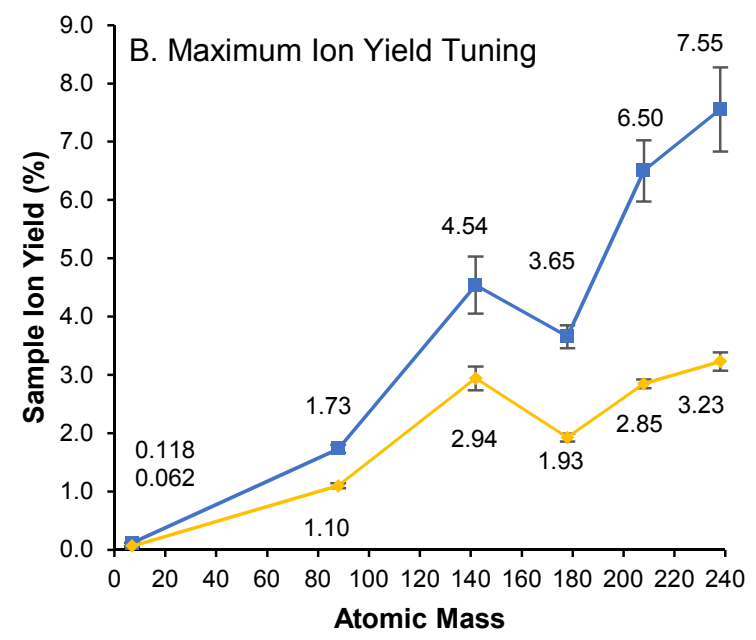

$\longrightarrow$ High Efficiency $\leadsto$ Conventional

Figure 1. Calculated sample ion yield (\%) on SRM610 v. atomic mass for the high efficiency and the conventional LA-MCICP-MS configurations. $50 \mu \mathrm{m}$ circle, $4 \mathrm{~J} \mathrm{~cm}^{-2}$ fluence, $1 \mathrm{~Hz}, 50$ shots. A. LA-MC-ICP-MS optimally tuned for low oxide formation. B. LA-MC-ICP-MS tuned for maximum ion yield. Error bars are $1 \mathrm{SD}, \mathrm{n}=4$. 


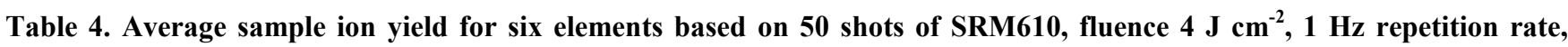
tuned for optimized conditions. Uncertainties reported are $1 S D, n=4$.

\begin{tabular}{llllllll}
\hline Spot Size & & $\mathbf{U}$ & $\mathbf{P b}$ & $\mathbf{H f}$ & $\mathbf{N d}$ & $\mathbf{S r}$ & $\mathbf{L i}$ \\
\hline $\mathbf{1 1 0} \boldsymbol{\mu \mathbf { m }}$ & High Efficiency & $4.00 \pm 0.17$ & $3.65 \pm 0.08$ & $1.71 \pm 0.07$ & $2.59 \pm 0.04$ & $1.08 \pm 0.02$ & $0.054 \pm 0.001$ \\
& Conventional & $2.03 \pm 0.07$ & $1.48 \pm 0.02$ & $1.57 \pm 0.10$ & $2.10 \pm 0.03$ & $0.92 \pm 0.05$ & $0.034 \pm 0.000$ \\
& \% Improvement & 97 & 146 & 9 & 23 & 16 & 61 \\
$\mathbf{8 5} \boldsymbol{\mu \mathbf { m }}$ & High Efficiency & $4.14 \pm 0.18$ & $3.65 \pm 0.09$ & $1.97 \pm 0.08$ & $2.90 \pm 0.13$ & $1.26 \pm 0.07$ & $0.057 \pm 0.001$ \\
& Conventional & $2.27 \pm 0.04$ & $1.59 \pm 0.09$ & $1.82 \pm 0.13$ & $2.33 \pm 0.08$ & $1.03 \pm 0.01$ & $0.037 \pm 0.001$ \\
& \% Improvement & 83 & 129 & 8 & 24 & 23 & 55 \\
$\mathbf{5 0} \boldsymbol{\mu \mathbf { m }}$ & High Efficiency & $4.35 \pm 0.04$ & $3.93 \pm 0.12$ & $3.23 \pm 0.10$ & $4.06 \pm 0.09$ & $1.79 \pm 0.10$ & $0.077 \pm 0.007$ \\
& Conventional & $2.03 \pm 0.14$ & $1.52 \pm 0.10$ & $1.75 \pm 0.08$ & $2.12 \pm 0.04$ & $0.98 \pm 0.05$ & $0.033 \pm 0.001$ \\
& \% Improvement & 114 & 159 & 85 & 92 & 83 & 131 \\
$\mathbf{2 0} \boldsymbol{\mu \mathbf { m }}$ & High Efficiency & $6.37 \pm 1.28$ & $6.82 \pm 1.37$ & $3.94 \pm 0.27$ & $4.14 \pm 0.30$ & $1.78 \pm 0.18$ & $0.073 \pm 0.010$ \\
& Conventional & $2.05 \pm 0.15$ & $1.46 \pm 0.21$ & $1.42 \pm 0.10$ & $1.72 \pm 0.29$ & $1.08 \pm 0.35$ & $0.029 \pm 0.002$ \\
& \% Improvement & 210 & 366 & 177 & 140 & 65 & 150 \\
$\mathbf{1 0} \boldsymbol{\mu \mathbf { m }}$ & High Efficiency & $5.43 \pm 2.58$ & $7.24 \pm 2.45$ & $3.86 \pm 0.23$ & $5.78 \pm 3.50$ & $2.47 \pm 0.80$ & $0.064 \pm 0.018$ \\
& Conventional & $1.82 \pm 0.42$ & $1.00 \pm 0.07$ & $1.07 \pm 0.19$ & $1.08 \pm 0.48$ & $0.80 \pm 0.24$ & $0.022 \pm 0.003$ \\
& \% Improvement & 263 & 626 & 262 & 436 & 208 & 194 \\
\hline
\end{tabular}

Table 5. Average sample ion yield for six elements based on 50 shots of SRM610, fluence $4 \mathrm{~J} \mathrm{~cm}^{-2}, 1 \mathrm{~Hz}^{\mathrm{repetition}}$ rate, tuned for maximum sample ion yield. Uncertainties reported are 1SD, $n=4$.

\begin{tabular}{llllllll}
\hline Spot Size & & $\mathbf{U}$ & $\mathbf{P b}$ & $\mathbf{H f}$ & $\mathbf{N d}$ & $\mathbf{S r}$ & $\mathbf{L i}$ \\
\hline $\mathbf{1 1 0} \boldsymbol{\mu \mathbf { m }}$ & High Efficiency & $5.11 \pm 0.22$ & $4.38 \pm 0.11$ & $1.21 \pm 0.03$ & $2.46 \pm 0.11$ & $0.80 \pm 0.03$ & $0.084 \pm 0.003$ \\
& Conventional & $3.52 \pm 0.11$ & $2.88 \pm 0.06$ & $1.45 \pm 0.05$ & $2.27 \pm 0.05$ & $1.05 \pm 0.04$ & $0.063 \pm 0.003$ \\
& \% Improvement & 45 & 52 & -17 & 8 & -24 & 33 \\
$\mathbf{8 5} \boldsymbol{\mu \mathbf { m }}$ & High Efficiency & $5.91 \pm 0.30$ & $5.11 \pm 0.16$ & $1.73 \pm 0.04$ & $2.95 \pm 0.15$ & $0.99 \pm 0.03$ & $0.089 \pm 0.005$ \\
& Conventional & $3.39 \pm 0.13$ & $2.99 \pm 0.15$ & $1.68 \pm 0.05$ & $2.51 \pm 0.13$ & $1.16 \pm 0.07$ & $0.065 \pm 0.003$ \\
& \% Improvement & 74 & 71 & 3 & 17 & -14 & 37 \\
$\mathbf{5 0} \boldsymbol{\mu \mathbf { m }}$ & High Efficiency & $7.55 \pm 0.72$ & $6.50 \pm 0.53$ & $3.65 \pm 0.19$ & $4.54 \pm 0.49$ & $1.73 \pm 0.07$ & $0.118 \pm 0.007$ \\
& Conventional & $3.23 \pm 0.16$ & $2.85 \pm 0.07$ & $1.93 \pm 0.07$ & $2.94 \pm 0.20$ & $1.10 \pm 0.04$ & $0.062 \pm 0.002$ \\
& \% Improvement & 134 & 104 & 90 & 54 & 58 & 91 \\
$\mathbf{2 0} \boldsymbol{\mu \mathbf { m }}$ & High Efficiency & $10.69 \pm 1.86$ & $9.94 \pm 0.92$ & $3.15 \pm 0.23$ & $4.12 \pm 0.40$ & $2.39 \pm 0.71$ & $0.109 \pm 0.008$ \\
& Conventional & $5.43 \pm 2.37$ & $3.47 \pm 0.38$ & $2.26 \pm 0.48$ & $3.23 \pm 0.22$ & $1.15 \pm 0.14$ & $0.068 \pm 0.008$ \\
& \% Improvement & 97 & 187 & 40 & 28 & 107 & 61 \\
$\mathbf{1 0} \boldsymbol{\mu \mathbf { m }}$ & High Efficiency & $10.00 \pm 1.23$ & $17.22 \pm 8.46$ & $2.75 \pm 0.99$ & $4.60 \pm 1.74$ & $2.13 \pm 0.80$ & $0.095 \pm 0.035$ \\
& Conventional & $4.80 \pm 3.14$ & $4.25 \pm 2.39$ & $1.94 \pm 0.16$ & $5.89 \pm 4.39$ & $1.00 \pm 0.37$ & $0.068 \pm 0.030$ \\
& \% Improvement & 108 & 306 & 41 & -22 & 112 & 39 \\
\hline
\end{tabular}

The reduction in sample ion yield at larger spot sizes was also associated with an increase in washout time. The spot sizes $50 \mu \mathrm{m}$ and below consequently showed the highest sample ion yields. At a spot size of $50 \mu \mathrm{m}$ the sample ion yield for $U$ averaged $7.55 \%$ when tuned for maximum signal and $4.35 \%$ in optimized (for low laser-induced elemental fractionation and oxide formation) tune conditions. Even higher sample ion yields were calculated for $\mathrm{U}$ and $\mathrm{Pb}$ with the 20 and $10 \mu \mathrm{m}$ spot sizes, however the uncertainty on the volume determinations were also significantly higher. The equivalent for the conventional configuration was $3.23 \%$ and $2.03 \%$ respectively. Using the high efficiency configu- ration effectively doubled the sample ion yield which could be achieved by the LA-MC-ICP-MS (Figure 1). Increases in sample ion yield were not limited to $\mathrm{U}$, but observed across the entire mass range at spot sizes smaller than $50 \mu \mathrm{m}$.

The sample ion yield of Hf was less than would be expected from its atomic mass, interpolating between $\mathrm{Nd}$ and $\mathrm{Pb}$ in Figure 1, but still approximately two times larger (3.65\% against $1.93 \%$ ) than for the conventional configuration. Due to its refractory nature and high ionization potential, Hf requires a significant amount of energy to fully ionize. In theory the residence time of the ablated material inside the ICP may have been insufficient to ionize all of the $\mathrm{Hf}$ atoms introduced (compared proportionately to $\mathrm{Nd}$ and $\mathrm{Pb}$ ). 
Table 6. $20 \mathrm{Hf}$ spot ablations on the Plešovice zircon, $25 \mu \mathrm{m}$ spot size, $6.5 \mathrm{~J} \mathrm{~cm}^{-2}$ fluence, $10 \mathrm{~Hz}$ repetition rate, $8 \mathrm{~s}$ duration.

\begin{tabular}{|c|c|c|c|c|c|c|c|c|c|c|c|c|c|c|c|c|}
\hline Spot & ${ }^{173} \mathbf{Y b}(\mathrm{V})$ & Total Hf (V) & ${ }^{178} \mathrm{Hf} /{ }^{177} \mathrm{Hf}$ & $2 \mathrm{SE}$ & ${ }^{179} \mathbf{H f}^{\mathbf{f l}^{177}} \mathbf{H f}$ & $2 \mathrm{SE}$ & ${ }^{176} \mathbf{Y b} /{ }^{177} \mathbf{H f}$ & $2 \mathrm{SE}$ & ${ }^{176} \mathrm{Lu} /{ }^{177} \mathrm{Hf}$ & $2 \mathrm{SE}$ & ${ }^{176} \mathbf{H f} /{ }^{1{ }^{177}} \mathbf{H} f_{c Y b}$ & $2 \mathrm{SE}$ & ${ }^{176} \mathbf{H f} /{ }^{177} \mathbf{H f}$ CF & 2SE & $\beta_{\mathrm{Hf}}$ & $\beta_{\mathrm{Yb}}$ \\
\hline Plešovice_1 & 0.064 & 44 & 1.467231 & 0.000046 & 0.740047 & 0.000039 & 0.006314 & 0.000046 & 0.0001562 & 0.0000009 & 0.282440 & 0.000021 & 0.282440 & 0.000024 & -0.911 & -0.710 \\
\hline Plešovice_2 & 0.064 & 42 & 1.467197 & 0.000052 & 0.739948 & 0.000059 & 0.006640 & 0.000160 & 0.0001562 & 0.0000008 & 0.282462 & 0.000020 & 0.282466 & 0.000021 & -0.899 & -0.653 \\
\hline Plešovice_3 & 0.062 & 41 & 1.467244 & 0.000045 & 0.739905 & 0.000041 & 0.006510 & 0.000130 & 0.0001565 & 0.0000004 & 0.282435 & 0.000020 & 0.282435 & 0.000022 & -0.894 & -0.690 \\
\hline Plešovice_4 & 0.057 & 41 & 1.467265 & 0.000045 & 0.739905 & 0.000054 & 0.006020 & 0.000140 & 0.0001442 & 0.0000005 & 0.282456 & 0.000025 & 0.282456 & 0.000027 & -0.894 & -0.686 \\
\hline Plešovice_5 & 0.060 & 41 & 1.467206 & 0.000046 & 0.739937 & 0.000048 & 0.006290 & 0.000140 & 0.0001533 & 0.0000004 & 0.282448 & 0.000015 & 0.282445 & 0.000016 & -0.897 & -0.718 \\
\hline Plešovice_6 & 0.064 & 42 & 1.467217 & 0.000048 & 0.739950 & 0.000050 & 0.006570 & 0.000100 & 0.0001584 & 0.0000009 & 0.282435 & 0.000025 & 0.282436 & 0.000024 & -0.899 & -0.683 \\
\hline Plešovice_7 & 0.062 & 42 & 1.467218 & 0.000046 & 0.739965 & 0.000042 & 0.006394 & 0.000075 & 0.0001590 & 0.0000008 & 0.282446 & 0.000021 & 0.282446 & 0.000022 & -0.901 & -0.691 \\
\hline Plešovice_8 & 0.059 & 41 & 1.467204 & 0.000047 & 0.739930 & 0.000032 & 0.006290 & 0.000150 & 0.0001495 & 0.0000005 & 0.282470 & 0.000025 & 0.282475 & 0.000027 & -0.897 & -0.648 \\
\hline Plešovice_9 & 0.056 & 41 & 1.467186 & 0.000039 & 0.739865 & 0.000051 & 0.005900 & 0.000170 & 0.0001370 & 0.0000005 & 0.282440 & 0.000020 & 0.282442 & 0.000023 & -0.889 & -0.670 \\
\hline Plešovice_10 & 0.061 & 40 & 1.467216 & 0.000051 & 0.739893 & 0.000051 & 0.006670 & 0.000140 & 0.0001578 & 0.0000003 & 0.282457 & 0.000018 & 0.282456 & 0.000021 & -0.892 & -0.702 \\
\hline Plešovice_11 & 0.061 & 43 & 1.467225 & 0.000050 & 0.740049 & 0.000044 & 0.006187 & 0.000048 & 0.0001538 & 0.0000008 & 0.282456 & 0.000020 & 0.282457 & 0.000022 & -0.911 & -0.677 \\
\hline Plešovice_12 & 0.060 & 43 & 1.467257 & 0.000049 & 0.740013 & 0.000045 & 0.006076 & 0.000051 & 0.0001503 & 0.0000010 & 0.282465 & 0.000020 & 0.282471 & 0.000022 & -0.907 & -0.639 \\
\hline Plešovice_13 & 0.060 & 43 & 1.467187 & 0.000042 & 0.739999 & 0.000044 & 0.006029 & 0.000068 & 0.0001479 & 0.0000006 & 0.282463 & 0.000021 & 0.282466 & 0.000024 & -0.905 & -0.666 \\
\hline Plešovice_14 & 0.059 & 43 & 1.467256 & 0.000043 & 0.739988 & 0.000041 & 0.006016 & 0.000059 & 0.0001485 & 0.0000006 & 0.282463 & 0.000019 & 0.282461 & 0.000024 & -0.904 & -0.710 \\
\hline Plešovice_15 & 0.060 & 43 & 1.467254 & 0.000054 & 0.740047 & 0.000038 & 0.006118 & 0.000029 & 0.0001525 & 0.0000011 & 0.282452 & 0.000022 & 0.282460 & 0.000024 & -0.911 & -0.613 \\
\hline Plešovice_16 & 0.059 & 43 & 1.467238 & 0.000037 & 0.740045 & 0.000048 & 0.005978 & 0.000048 & 0.0001484 & 0.0000005 & 0.282450 & 0.000021 & 0.282450 & 0.000019 & -0.910 & -0.690 \\
\hline Plešovice_17 & 0.059 & 43 & 1.467291 & 0.000054 & 0.740015 & 0.000035 & 0.005962 & 0.000044 & 0.0001480 & 0.0000006 & 0.282457 & 0.000020 & 0.282457 & 0.000020 & -0.907 & -0.690 \\
\hline Plešovice_18 & 0.059 & 43 & 1.467224 & 0.000046 & 0.740049 & 0.000042 & 0.006016 & 0.000050 & 0.0001491 & 0.0000005 & 0.282443 & 0.000019 & 0.282452 & 0.000022 & -0.911 & -0.605 \\
\hline Plešovice_19 & 0.059 & 43 & 1.467237 & 0.000049 & 0.740008 & 0.000041 & 0.005968 & 0.000055 & 0.0001478 & 0.0000010 & 0.282458 & 0.000019 & 0.282461 & 0.000021 & -0.906 & -0.670 \\
\hline \multirow[t]{2}{*}{ Plešovice_20 } & 0.059 & 43 & 1.467219 & 0.000047 & 0.740007 & 0.000037 & 0.005992 & 0.000049 & 0.0001482 & 0.0000010 & 0.282452 & 0.000021 & 0.282452 & 0.000024 & -0.906 & -0.690 \\
\hline & ${ }^{173} \mathrm{Yb}(\mathrm{V})$ & Total Hf (V) & ${ }^{178} \mathbf{H f} /{ }^{177} \mathbf{H f}$ & $2 \mathrm{SE}$ & ${ }^{179} \mathbf{H f}{ }^{1177} \mathbf{H f}$ & $2 \mathrm{SE}$ & ${ }^{176} \mathbf{Y b} /{ }^{177} \mathbf{H f}$ & 2SE & ${ }^{176} \mathbf{L u} /{ }^{177} \mathbf{H f}$ & $2 \mathrm{SE}$ & ${ }^{176} \mathbf{H f} /{ }^{177} \mathbf{H f}_{\mathrm{c}} \mathrm{Yb}$ & 2SE & ${ }^{176} \mathbf{H f} /{ }^{177} \mathbf{H} \mathbf{f}_{\mathrm{CF}}$ & 2SE & $\beta_{\mathrm{HF}}$ & $\beta_{\mathrm{Yb}}$ \\
\hline Mean & 0.060 & 42 & 1.467229 & 0.000047 & 0.739978 & 0.000044 & 0.006197 & 0.000088 & 0.0001511 & 0.0000007 & 0.282452 & 0.000021 & 0.282454 & 0.000022 & -0.902 & -0.675 \\
\hline 2SD & & & 0.000056 & & 0.000046 & & & & & & 0.000020 & & 0.000022 & & & \\
\hline 2RSD (ppm) & & & 38 & & 63 & & & & & & 72 & & 79 & & & \\
\hline
\end{tabular}


All reported sample ion yields were based on the average of four 50 shot ablations. However, when ablating a crater using a static spot, the amount of signal generated decreases over time - ablation efficiency decreases as the hole depth increases below the depth of field of the laser focus. For the smallest $(10 \mu \mathrm{m})$ spot size determined, a $48 \%$ decrease in measured signal was observed between the first 5 shots and last 5 shots ablated. There was a corresponding $22 \%$ signal decrease for the $20 \mu \mathrm{m}$ spot size and a $7 \%$ signal decrease at $50 \mu \mathrm{m}$. Compared to the overall efficiencies reported in Table 6 , assuming consistent ablation, we can calculate the first five shots were $36 \%, 11 \%$ and $1.5 \%$ more efficient for 10 $\mu \mathrm{m}, 20 \mu \mathrm{m}$ and $50 \mu \mathrm{m}$ spot sizes respectively. The higher peak sample ion yields are important considerations given single pulse laser ablation ${ }^{26,27}$ and sample surface rastering, e.g. for mapping, where these peak sample ion yields would be maintained. More generally, higher peak sample ion yields for near surface ablation advocates increasing utilization of shallower, better spatially constrained, laser ablation methodologies which can still achieve required precisions.

A sample ion yield $>7 \%$ for $U$ represents a significant increase on values which have been previously reported for MC-ICP-MS, either by laser ablation or any other sample introduction technique. The maximum sample ion yield of $U$ $(\leq 3.5 \%)$ previously reported using a desolvating nebulizer system $^{28}$ are similar to the value measured here for laser ablation using the conventional configuration. We can hypothesize that a further optimization of sample introduction using desolvating nebulizers, based on the principles developed for high efficiency laser ablation, may yield similar improvements in sample ion yields for solution analysis.

Pb Isotopic Analysis of MPI-DING Reference Materials. A normal LA-MC-ICP-MS analysis would require a faster repetition rate than the $1 \mathrm{~Hz}$ this study used to determine the sample ion yield in order to achieve a smooth signal profile. The fast washout time of the ARIS on a single collector ICPMS would require a very high repetition rate $(>40 \mathrm{~Hz})$ to achieve a smooth signal profile. Ultimately the utility of rapid response ablation cells to routine LA trace elemental analysis of the complete mass range with a scanning, single collector instrument, is limited by spectral skew until the introduction of a signal smoothing device. The slower tau response of the Faraday cup detectors in the MC-ICP-MS already smooth the signal profile such that rates $>8 \mathrm{~Hz}$ are sufficient. By eliminating the requirement for high repetition rates, which lead to rapid ablation through a sample, Faraday detectors allow rapid response laser ablation cells to be used in routine LA-MC-ICP-MS analysis, taking advantage of the higher sample ion yields prevalent at lower ablation rates. Note if a mixed detector array of Faraday and SEM detectors was used a higher repetition rate would be needed to avoid spectral skew on the SEM portion of the measurement.

Similarly to when calculating the sample ion yield, the $\mathrm{Pb}$ isotope ion yield was between $85-105 \%$ higher for the SRM612 standard when using the high efficiency configuration (Table 7.) whilst maintaining equivalent ${ }^{208} \mathrm{~Pb} /{ }^{206} \mathrm{~Pb}$ and ${ }^{207} /{ }^{206} \mathrm{~Pb}$ accuracy compared to the conventional laser con- figuration, allowing for the determined uncertainty. For ATHO-G and GOR132-G the ${ }^{208} \mathrm{~Pb} /{ }^{206} \mathrm{~Pb}$ repeatability was nearly identical for both configurations; for StHs6/80-G the $2 \mathrm{SD}$ was lower for the conventional configuration $(0.13 \mathrm{v}$ $0.17 \%$ ). The repeatability of ${ }^{207} \mathrm{~Pb} /{ }^{206} \mathrm{~Pb}$ was much improved by the increased signal of the high efficiency configuration for all three reference glasses.

Hf isotope ratio analysis and $\mathrm{U} / \mathrm{Pb}$ geochronology of reference zircons. The demanding precision requirements of ${ }^{176} \mathrm{Hf} /{ }^{177} \mathrm{Hf}$ analysis requires sufficient ablated material to satisfy counting statistics. Typically this is achieved by using relatively large spot sizes of $35-50 \mu \mathrm{m}$. A potential consequence of using a larger spot size in complex zircons is that the measured ${ }^{176} \mathrm{Hf} /{ }^{177} \mathrm{Hf}$ may be decoupled from the age measured at the same or an adjacent location. Efforts have therefore been ongoing to reduce the amount of material required for ${ }^{176} \mathrm{Hf} /{ }^{177} \mathrm{Hf}$ analysis in zircons.

Bauer \& Horstwood (2017) reported achieving the required precision on ${ }^{176} \mathrm{Hf} /{ }^{177} \mathrm{Hf}$ with a LA-MC-ICP-MS spot ablation, 100 shots at $10 \mathrm{~Hz}, 25 \mu \mathrm{m}$ circle, $6.5 \mathrm{Jcm}^{-2}$. For the common reference zircon Plešovice this equated to an average of $25 \mathrm{~V} / \mathrm{s}$ total Hf signal for $40 \mathrm{ng}$ of total zircon ablated. Using the same laser conditions in conjunction with the high efficiency rapid response laser ablation cell yielded $42 \mathrm{~V} / \mathrm{s}$ of total Hf signal (Table 6) maintaining ${ }^{176} \mathrm{Hf} /{ }^{177} \mathrm{Hf}$ uncertainties $<1 \varepsilon(2 \mathrm{~s})$. Reducing the spot size further to $20 \mu \mathrm{m}$ the total Hf measured for Plešovice was still $29 \mathrm{~V} / \mathrm{s}$ (supplementary data). Assuming the same ablation rate for these fluences between the two systems, this is equivalent to just 26 ng of total ablated zircon.

Using an identical $20 \mu \mathrm{m}$ spot size $\mathrm{Pb} / \mathrm{Pb}$ ages were determined for the same reference zircons. The signal intensity on the 91500 zircon was $123 \%$ higher for the high efficiency laser ablation configuration compared to the conventional configuration. This corresponded to a reduction in uncertainty on the ${ }^{207} \mathrm{~Pb} /{ }^{206} \mathrm{~Pb}$ age from $2.26 \%$ to $0.80 \%$ (2SD, $\left.\mathrm{n}=10\right)$.

\section{CONCLUSION}

Coupling LA-MC-ICP-MS with high efficiency laser ablation designs has been demonstrated to double the sample ion yield. We demonstrate these designs can be used successfully to measure routine LA-MC-ICP-MS applications with better isotope ratio precision and spatial resolution.

A sample ion yield of greater than $7 \%$ for $U$ (and potentially up to $8-9 \%$ for $\mathrm{U}$ and $\mathrm{Pb}$ ) represents a new maximum in the field of MC-ICP-MS and confirms that limitations in ion yield for this technique are principally related to the sample introduction system. Incorporating some of the technological developments from high efficiency laser ablation designs into other sample introduction systems within ICP-MS may lead to similar improvements in ion yield. This would be of great benefit to analyses, in varied fields such as cosmochemistry, environmental monitoring and nuclear safeguards where the amount of sample material available is limited. 


\begin{tabular}{|c|c|c|c|c|c|c|c|c|c|c|}
\hline & & $\begin{array}{l}{ }^{206} \mathbf{P b} \\
(\mathrm{mV})\end{array}$ & $\begin{array}{l}{ }^{207} \mathrm{~Pb} \\
(\mathrm{mV})\end{array}$ & $\begin{array}{l}{ }^{208} \mathrm{~Pb} \\
(\mathrm{mV})\end{array}$ & ${ }^{208} \mathrm{~Pb} /{ }^{206} \mathrm{~Pb}$ & 2SD & 2RSD (\%) & ${ }^{207} \mathrm{~Pb} /{ }^{206} \mathrm{~Pb}$ & 2SD & $\begin{array}{l}\text { 2RSD } \\
(\%)\end{array}$ \\
\hline \multirow[t]{2}{*}{$\begin{array}{l}\text { ATHO-G } \\
(5.5 \mu \mathrm{g} / \mathrm{g})\end{array}$} & $\begin{array}{l}\text { High } \\
\text { Efficiency }\end{array}$ & 7.6 & 6.5 & 15.8 & 2.0746 & 0.0056 & 0.27 & 0.8427 & 0.0012 & 0.14 \\
\hline & Conventional & 3.3 & 2.8 & 6.6 & $\begin{array}{l}2.0723 \\
\text { (Ref: } 2.0735)\end{array}$ & 0.0058 & 0.28 & $\begin{array}{l}0.8419 \\
\text { (Ref: } 0.8421)\end{array}$ & 0.0025 & 0.30 \\
\hline \multirow[t]{2}{*}{$\begin{array}{l}\text { GOR132-G } \\
(20.25 \mu \mathrm{g} / \mathrm{g})\end{array}$} & $\begin{array}{l}\text { High Efficien- } \\
\text { cy }\end{array}$ & 32.2 & 26.4 & 64.4 & 2.0081 & 0.0023 & 0.11 & 0.8160 & 0.00044 & 0.054 \\
\hline & Conventional & 16.6 & 13.6 & 32.5 & $\begin{array}{l}2.0087 \\
\text { (Ref: } 2.0095)\end{array}$ & 0.0023 & 0.11 & $\begin{array}{l}0.8166 \\
\text { (Ref: } 0.8163 \text { ) }\end{array}$ & 0.00054 & 0.066 \\
\hline \multirow[t]{2}{*}{$\begin{array}{l}\text { StHs6/80-G } \\
(10.25 \mu \mathrm{g} / \mathrm{g})\end{array}$} & $\begin{array}{l}\text { High } \\
\text { Efficiency }\end{array}$ & 19.72 & 16.40 & 38.70 & 2.0368 & 0.0034 & 0.17 & 0.8259 & 0.00038 & 0.046 \\
\hline & Conventional & 7.21 & 5.99 & 14.33 & $\begin{array}{l}2.0364 \\
\text { (Ref: } 2.0380)\end{array}$ & 0.0026 & 0.13 & $\begin{array}{l}0.8262 \\
\text { (Ref: } 0.8263)\end{array}$ & 0.00092 & 0.111 \\
\hline
\end{tabular}

Table 7. ${ }^{208} \mathrm{~Pb} /{ }^{206} \mathrm{~Pb}$ and ${ }^{207} \mathrm{~Pb} /{ }^{206} \mathrm{~Pb}$ isotope ratio results for three MPI-DING glasses. $40 \mu \mathrm{m}$ spot size, $3 \mathrm{~J} \mathrm{~cm}^{-2}$ fluence, $16 \mathrm{~Hz}$ repetition rate, $22 \mathrm{~s}$ duration.

\section{ASSOCIATED CONTENT}

\section{Supporting Information}

Sample ion yield signal intensity, $\mathrm{Hf}$ and $\mathrm{U} / \mathrm{Pb}$, enhanced single crater image, data reduction schemes for $\mathrm{Pb}$ and $\mathrm{Hf}$ (.docx)

Crater volume measurement (PDF)

\section{AUTHOR INFORMATION}

\section{Corresponding Author}

* E-mail address: grant.craig@thermofisher.com, phone number +494215493130.

\section{Notes}

Dr. Grant Craig and Dr. Nicholas Lloyd are employed by Thermo Fisher Scientific (Bremen) GmbH. Dr. Ciprian Stremtan is employed by Teledyne CETAC Technologies.

\section{REFERENCES}

(1) Wang, H. A. O.; Grolimund, D.; Giesen, C.; Borca, C. N.; Shaw-Stewart, J. R. H.; Bodenmiller, B.; Günther, D. Anal. Chem. 2013, 85, 10107-10116.

(2) Van Malderen, S. J. M.; van Elteren, J. T.; Vanhaecke, F. J. Anal. At. Spectrom. 2015, 30, 119-125.

(3) Douglas, D. N.; Managh, A. J.; Reid, H. J.; Sharp, B. L. Anal. Chem. 2015, 87, 11285-11294.

(4) Van Malderen, S. J. M.; Managh, A. J.; Sharp, B. L.; Vanhaecke, F. J. Anal. At. Spectrom. 2016, 31, 423-439.

(5) Managh, A. J.; Horstwood, M. S. a.; Reid, H. J.; Sharp, B. L. In 13th European Workshop on Laser Ablation; Ljubljana, 2016.

(6) Van Malderen, S. J. M.; van Elteren, J. T.; Šelih, V. S.; Vanhaecke, F. Spectrochim. Acta - Part B At. Spectrosc. 2018, 140, $29-34$.

(7) Breglio, A. M.; Rusheen, A. E.; Shide, E. D.; Fernandez, K. A.; Spielbauer, K. K.; McLachlin, K. M.; Hall, M. D.; Amable, L.; Cunningham, L. L. Nat. Commun. 2017, 8, 1654-1662.

(8) Theiner, S.; Van Malderen, S. J. M.; Van Acker, T.; Legin, A.; Keppler, B. K.; Vanhaecke, F.; Koellensperger, G. Anal. Chem. 2017, 89, 12641-12645.

(9) Van Malderen, S. J. M.; Laforce, B.; Van Acker, T.; Nys, C.; De Rijcke, M.; De Rycke, R.; De Bruyne, M.; Boone, M. N.; De Schamphelaere, K.; Borovinskaya, O.; De Samber, B.; Vincze, L.; Vanhaecke, F. Anal. Chem. 2017, 89, 4161-4168.

(10) Petrus, J. A.; Chew, D. M.; Leybourne, M. I.; Kamber, B. S. Chem. Geol. 2017, 463, 76-93.
(11) Craig, G. PhD. Dissertation, Loughborough University, 2015 .

(12) Fisher, C. M.; Vervoort, J. D.; Dufrane, S. A. Geochemistry, Geophys. Geosystems 2014, 15, 121-139.

(13) Bauer, A. M.; Horstwood, M. S. A. Chem. Geol. 2017, 476, 85-99.

(14) Schaltegger, U.; Schmitt, A. K.; Horstwood, M. S. A. Chem. Geol. 2015, 402, 89-110.

(15) Johnston, S.; Gehrels, G.; Valencia, V.; Ruiz, J. Chem. Geol. 2009, 259, 218-229.

(16) Horstwood, M. S. A.; Košler, J.; Gehrels, G.; Jackson, S. E.; McLean, N. M.; Paton, C.; Pearson, N. J.; Sircombe, K.; Sylvester, P.; Vermeesch, P.; Bowring, J. F.; Condon, D. J.; Schoene, B. Geostand. Geoanalytical Res. 2016, 40, 311-332.

(17) Kimura, J.-I.; Chang, Q.; Kanazawa, N.; Sasaki, S.; Vaglarov, B. S. J. Anal. At. Spectrom. 2016, 31, 790-800.

(18) Lloyd, N. S.; Sadekov, A. Y.; Misra, S. Rapid Commun. Mass Spectrom. 2018, 32, 9-18.

(19) Cottle, J. M.; Burrows, A. J.; Kylander-Clark, A. R.; Freedman, P. A.; Cohen, R. S. J. Anal. At. Spectrom. 2013, 28, $1700-1706$.

(20) Hieftje, G. M.; Mermet, J.-M.; Hill, S. J.; Fisher, A.; Foulkes, M.; Sharp, B. L.; O'Connor, C.; O'Connor, G.; Evans, E. H.; Vanhaeke, F.; Balcaen, L.; Taylor, P.; Hansen, H. R.; Pergantis, S. A. Inductively Coupled Plasma Spectroscopy and its Applications, 2nd ed.; Hill, S. J., Ed.; Blackwell Publishing: Oxford, 2007.

(21) Ranebo, Y.; Hedberg, P. M. L.; Whitehouse, M. J.; Ingeneri, K.; Littmann, S. J. Anal. At. Spectrom. 2009, 24, 277-287.

(22) Gerstenberger, H.; Haase, G. Chem. Geol. 1997, 136, $309-312$.

(23) Bürger, S.; Riciputi, L. R.; Bostick, D. A.; Turgeon, S.; McBay, E. H.; Lavelle, M. Int. J. Mass Spectrom. 2009, 286, 70-82.

(24) Payne, J. L.; Pearson, N. J.; Grant, K. J.; Halverson, G. P. J. Anal. At. Spectrom. 2013, 28, 1068-1079.

(25) Fisher, C. M.; McFarlane, C. R. M.; Hanchar, J. M.; Schmitz, M. D.; Sylvester, P. J.; Lam, R.; Longerich, H. P.; Chem. Geol., 2011, 284, 1-20.

(26) Cottle, J. M.; Horstwood, M. S. a.; Parrish, R. R. J. Anal. At. Spectrom. 2009, 24, 1355-1363.

(27) Cottle, J. M.; Kylander-Clark, A. R.; Vrijmoed, J. C. Chem. Geol. 2012, 332-333, 136-147.

(28) Neptune Plus Multicollector ICPMS, Another step ahead in MC-ICP-MS, Thermo Scientific BR30197-E01/12G, Thermo Fisher Scientific, Bremen, 2011. 
Authors are required to submit a graphic entry for the Table of Contents (TOC) that, in conjunction with the manuscript title, should give the reader a representative idea of one of the following: A key structure, reaction,

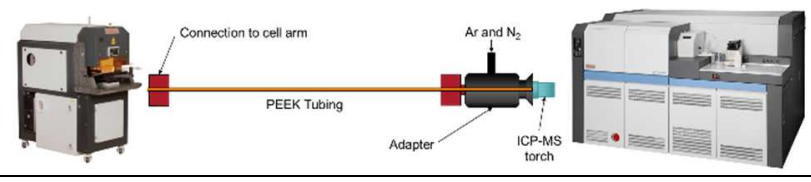

equation, concept, or theorem, etc., that is discussed in the manuscript. Consult the journal's Instructions for Authors for TOC graphic specifications.

Insert Table of Contents artwork here 